\title{
PHYSIOLOGICAL AND PHENOLOGICAL VEGETATIVE RESPONSES OF Campomanesia adamantium (Cambess) O. Berg (Myrtaceae) TO THE HYDRIC SEASONALITY OF RUPESTRIAN FIELDS ${ }^{1}$
}

\author{
Vinícius Coelho Kuster ${ }^{2 *}$, Mateus Scarpelli Aguiar Marcato de Paula ${ }^{2}$, Silvana Aparecida Barbosa de \\ Castro $^{3}$ and Fernando Henrique Aguiar Vale ${ }^{4}$
}

\begin{abstract}
${ }^{1}$ Received on 14.01.2016 accepted for publication on 05.10.2016.
${ }^{2}$ Universidade Federal de Minas Gerais, Programa de Pós Graduação em Biologia Vegetal, Belo Horizonte, Minas Gerais, Brasil.E-mail:<viniciusck_bio@hotmail.com>and<scarpasbh@hotmail.com>.

${ }^{3}$ Universidade Federal de Minas Gerais, Programa de Pós Graduação em Ecologia, Conservação e Manejo da Vida Silvestre, Belo Horizonte, Minas Gerais, Brasil. E-mail: <silvana.abcastro@gmail.com>.

${ }^{4}$ Universidade Federal de Minas Gerais, Departamento de Botânica, Belo Horizonte, Minas Gerais, Brasil. E-mail: $<$ fvale@icb.ufmg.br>.

*Corresponding author.
\end{abstract}

\begin{abstract}
The rupestrian fields have two well-defined seasons throughout the year, with rainfall rates that reflect the rainy and dry seasons. This distinction in water availability affects the morphology, physiology and chemistry of plants, among other characteristics. Thus, it is aimed at evaluating the leaf water status, vegetative phenology and photosynthetic behavior of Campomanesia adamantium from a rupestrian field during the dry and rainy season. The study was conducted in Serra do Cipó, Minas Gerais, Brazil. From November 2011 to November 2012 it was examined vegetative phenophases and development of six individuals. Water potential, stomatal conductance, quantum yield and concentration of pigments were evaluated from four leaves of 3 rd node per individual $(n=4-5)$ in the dry and rainy seasons. $C$. adamantium is an evergreen type and presents mature leaves and sprouting throughout the year. This species showed strategies that reduce water loss during the dry season in rupestrian field, such as decrease in stomatal conductance throughout the day, also associated with a reduction in leaf water potential. However, low water availability did not affect the photosynthetic performance, which enables the construction of new leaves and renovation of the crown even in dry periods. Finally, little reduction in the values of $\mathrm{Fv} / \mathrm{Fm}$ throughout the day and increase the values of $\Delta \mathrm{F} / \mathrm{Fm}^{\prime}$ in warmer times, both in the dry season, reiterates the ability of $C$. adamantium to adjust their physiology to seasonal water deficit of the rupestrian field.
\end{abstract}

Keywords: Stomatal conductance; Water potential; Quantum yield.

\section{RESPOSTAS FISIOLÓGICAS E FENOLÓGICAS VEGETATIVAS DE Campomanesia adamantium (Cambess) O. Berg (Myrtaceae) À SAZONALIDADE HÍDRICA DO CAMPO RUPESTRE}

\begin{abstract}
RESUMO-Os campos rupestres apresentam duas estações bem definidas ao longo do ano, com taxas pluviométricas que refletem nas estações chuvosa e seca. Essa distinção na disponibilidade hídrica afeta a morfologia, fisiologia, química, dentre outras características das plantas. Dessa forma objetivou-se avaliar o status hidrico foliar, o comportamento fenológico vegetativo e fotossintético de Campomanesia adamantium em campo rupestre durante a estação seca e chuvosa. O estudo foi conduzido na Serra do Cipó, Minas Gerais, Brasil. De novembro de 2011 a novembro de 2012 foi averiguado as fenofases vegetativas e o desenvolvimento de seis individuos. Potencial hídrico, condutância estomática, rendimento quântico e concentração de pigmentos foram adquiridos de quatro folhas do $3^{\circ}$ nó por individuo $(n=4-5)$ nas estações seca e chuvosa. C. adamantium é uma espécie sempre-verde e apresenta folhas maduras e brotamento ao longo de todo o ano. Essa espécie demonstrou
\end{abstract}


estratégias que minimizam a perda de água durante o período seco no campo rupestre, como diminuição na condutância estomática ao longo do dia na estação seca, associada também com redução nos valores de potencial hídrico foliar. Entretanto, a baixa disponibilidade hídrica não afetou no desempenho fotossintético, o que possibilita a construção de folhas novas e renovação da copa mesmo em periodos mais secos. Por fim, a pouca redução nos valores de Fv/Fm ao longo do dia e aumento nos valores de $\Delta F / F m$ 'em horários mais quentes, ambos na estação seca, reitera a capacidade de . adamantium em ajustar sua fisiologia ao déficit hidrico sazonal do campo rupestre.

Palavras-chave: Condutância estomática; Potencial hídrico; Rendimento quântico.

\section{INTRODUCTION}

Rupestrian fields typically have two well-defined seasons during the course of the year, a rainy season and a dry season, which are determined by rates of rainfall (BELO et al., 2013). Seasonal water deficit in plant species of Neotropical savannas occurs primarily in the upper layers of the soil in the dry season (FRANCO, 2002), and is responsible for frequent fires (NEVES; CONCEIÇÃO, 2010), while in the rainy season water restriction is limited to critical periods during the course of a day (MEINZER et al., 1999). Water deficit can trigger a series of deficiencies for vegetative development, as well as for the photosynthetic apparatus (BAKER, 1993) and transpiration rates (NAVESBARBIERO et al., 2000), which require physiological adjustments by the plant species that colonize seasonal environments.

Rupestrian fields contain a rich floristic composition and a high number of endemic and endangered species (MENDONÇA; LINS, 2000; SILVEIRA et al., 2016). They are found in the states of Minas Gerais, Bahia and Goiás and the Distrito Federal (GIULIETTI et al., 2000). In Minas Gerais, Rupestrian fields are inserted in the Cerrado (GIULIETTI et al., 1987) then, fits in this Biome (EITEN, 1972; 2001). Rupestrian fields occur at elevations above 900 meters and have a predominantly herbaceous-shrub physiognomy with underdeveloped small trees (RAPINI et al., 2008; VASCONCELOS, 2011). According to Rapini et al. (2008), the Espinhaço Mountain Range contains most of the Brazilian Rupestrian fields, occurring from north of Chapada Diamantina in Bahia, to a Serra de Ouro Branco, in Minas Gerais.

The vegetation of Rupestrian fields is predominantly xeromorphic, with plants that are well adapted to oligotrophic and acidic soils, exposure to intense radiation, high winds and hydric limitations (GIULIETTI et al., 1997). Structures such as xylopodia provide an adequate water balance in certain species, even during critical periods of the year (KOLBEK; ALVES, 2008). Different strategies are also observed regarding vegetative phenology, which enables carbon balance and more efficient water use throughout the year (OLIVEIRA, 1998). Evergreen species maintain leaves in their crown throughout the year, while deciduous and semi-deciduous species completely loose their foliage, usually during periods of the year with high evaporative demand of the air, thereby reducing the transpiration rate (SARMIENTO et al., 1985; FRANCO et al., 2005).

Although there is a great amount of knowledge on the flora of Rupestrian fields, studies evaluating ecophysiological strategies have been scarce. In general, it is known that under low water availability and high exposure to light, the photosynthetic system can become photoinhibited and generate significant reductions in photosynthesis (KRAUSE; WEIS, 1991). Damage to the photosynthetic apparatus due to excessive light has been observed in woody species of the Cerrado (LÜTTGE et al., 1998; LEMOS-FILHO, 2000). For Chamaecrista semaphora, an endemic species of Rupestrian fields, decreases in water potential were observed in the middle of the day, accompanied by a significant decrease in values of potential quantum yield of photosystem II (CASTRO et al., 2016). In conjunction, the evaluation of chloroplastid pigment content can also show the fit of plants to their environment and are indicative of stress in plants because it demonstrates the efficiency of light absorption and energy transfer to the photosynthetic apparatus (SOUZA et al., 2011).

The genus Campomanesia Ruiz \& Pav. (Myrtaceae) is represented by groups of trees and shrubs belonging to the tribe Myrteae D.C. (LANDRUM, 1982). There are 29 species distributed from Argentina to the island of Trinidad (KAWAZAKI, 2000). Campomanesia 
adamantium (Cambess.) O. Berg is a species native to Brazil, where it is popularly known as "guabiroba" (LORENZI et al., 2006). Its fruits contain 30 essential oil components (VALLILO et al., 2006), which are used for making liquors, juices and sweets (PIVA, 2002). The leaves are marketed in Brazil and are used for the treatment of diarrhea and urinary problems (PIVA, 2002).

The objective was to evaluate leaf water status and vegetative phenological and photosynthetic behavior of Campomanesia adamantium (Cambess.) O. Berg (Myrtaceae) in an area of Rupestrian field, in order to determine the strategies employed during the dry and rainy seasons. It is hypothesized that seasonal variation in water availability in Rupestrian fields enables: 1) Greater investment in photoassimilates for growth in canopy area and in size of individuals in the rainy season; 2) Greater budding preceding and during the rainy season; 3 ) Decrease in potential and effective quantum yield in the dry season; and 4) Decrease in leaf water potential and stomatal conductance in the dry season.

\section{MATERIALAND METHODS}

The study was conducted in a Rupestrian field (2001'90"S, 4334'105"W), in Serra do Cipó (Espinhaço Mountain Range, Minas Gerais, Brazil). Ecophysiology and vegetative phenology were analyzed for Campomanesia adamantium (Cambess.) O. Berg (Myrtaceae). Voucher material was incorporated into the herbarium of the Universidade Federal de Minas Gerais (BHCB), with the record number 167052. Rainfall data for November 2011 to November 2012 from the Diamantina/Minas Gerais climatic station was made available by the Instituto Nacional de Meteorologia (INMET, 2015).

\subsection{Leaf development and phenology}

Monthly (November 2011 - November 2012) measurements were made of six individual plants for plant height (distance measured between the base of the stem and the highest green branch), and length and width of the canopy, with the aid of a tape measure. The area of the canopy was calculated using the formula for the area of an ellipse: $A=a . b . \pi$ (where $a=$ is the semi-axis of the larger, and $b=$ the semi-axis of the smaller diameter). During the same period, phenophases were recorded: 1- budding; 2- mature and green leaves; and 3- leaf fall.

\subsection{Measurements of stomatal conductance, chlorophyll $a$ fluorescence, leaf water status and pigments}

All parameters were evaluated in the field, except the pigments, in leaves of the $3^{\text {rd }}$ node of 4 or 5 individuals per season. Results for the raining season were obtained in February 2012, while the results for the dry season were obtained in August 2012, both on sunny, cloudless days.

Stomatal conductance (gs) was measured using a Model LI-1600 LI-COR porometer every two hours between 08:00-16:00 h. Readings were conducted on the abaxial surface of the median third of the leaves.

Leaf water potential $(\psi)$ was analyzed during predawn hours $(05: 00-06: 00 \mathrm{~h})$, in the middle of the day (12:00-14:00 $\mathrm{h})$ and in the afternoon (16:00 -17:00 h), using a Model 600 PMS pressure chamber (PMS Instruments, Covalis, Oregon, USA).

The quantum yield of photosystem II (PSII) was evaluated during the same period that stomatal conductance was evaluated using a modulated fluorescence meter (MINI-PAM, Walz). For effective quantum yield ( $\Delta \mathrm{F} / \mathrm{Fm}$ ') the leaves were subjected to direct incidence of radiation, and for the measures of potential quantum yield ( $\mathrm{Fv} / \mathrm{Fm})$ the leaves were adapted to the dark for 30 minutes. The light pulse used was $3000 \mathrm{mmol} \mathrm{m}^{-2} \mathrm{~s}^{-1}$ and lasted $800 \mathrm{~ms}$ (RASCHER et al., 2000). The $\Delta \mathrm{F} / \mathrm{Fm}$ ' was calculated as (Fm'-F)/ Fm', where $\mathrm{F}$ is the fluorescence at a steady state and Fm' is the maximum fluorescence after a saturating light pulse. For Fv/Fm, Fm is the maximum fluorescence emitted after a pulse of saturating light, and $\mathrm{Fv}=\mathrm{F}_{\mathrm{m}}-$ $\mathrm{F}_{0}\left(\mathrm{~F}_{0}\right.$ minimum fluorescence of darkened leaf) (GENTY et al., 1989).

For determining the concentration of photosynthetic pigments, four leaf discs of $1 \mathrm{~cm}^{2}$ were obtained from the middle third of 4 leaves from the $3^{\text {rd }}$ node of each individual plant in both the dry and the rainy seasons. The discs were immersed in $80 \%$ acetone in the field, stored in amber bottles, and transported in coolers for analysis 48 hours later. Maceration was conducted in a bright room with green light. The samples were centrifuged at $1000 \mathrm{rpm}$ for 5 minutes in a Fanen Model 206BL centrifuge. Absorbance of the supernatant was read at 470, 646 and $663 \mathrm{~nm}$ using a spectrophotometer (Thermo Spectronic Mod. Genesys 10UV). The calculation

Revista Árvore, Viçosa-MG, v.40, n.6, p.973-981, 2016 
of the concentration of chlorophyll $a$, chlorophyll $b$, total chlorophyll and carotenoids were performed according to Lichtenthaler and Wellburn (1983).

\subsection{Statistical Analysis}

Normality and homogeneity of the data were tested with Shapiro-Wilk's test and Levene test, respectively, prior to performing a one-way ANOVA followed by Tukey and/orT-test for parametric results. Kruskal-Wallis followed by Dunnett's test were adopted for nonparametric data. The Software JMP 5.0 (SAS Institute) was used to compare the results obtained in the dry and rainy season. In all the analyses a 5\% significance was adopted.

\section{RESULTS}

\subsection{Rainfall}

Rainfall equal to or greater than $300 \mathrm{~mm}$ was observed from November 2011 to January 2012 and in November 2012 (Figure 1A), representing the months of the greatest rainfall in the rainy season. In the dry season, July and August were the months with the least amount of rainfall, being less than $20 \mathrm{~mm}$ (Figure 1A).

\subsection{Development and leaf phenology}

The average growth in height of individual plants was $14 \%$ over the sample period, with the highest average being in November 2012 (Figure 1B). Reduction in the average height of individual plants was recorded at the end of the rainy season in March (Figure 1B). The canopy area was greatest during the dry season in April and May, with lower values in March (Figure 1C).

The studied individuals maintained mature, green leaves throughout the year (Figure 1D). Budding leaves were not observed between June and August, with leaf production in all individuals being in September and October (Figure 1D). This phenophase occurred in all months of the rainy season, but varied among the evaluated individuals (Figure 1D). Leaf abscission was observed both in the dry and rainy seasons, but only in July and August did this phenophase occur in all individuals (Figure 1D).

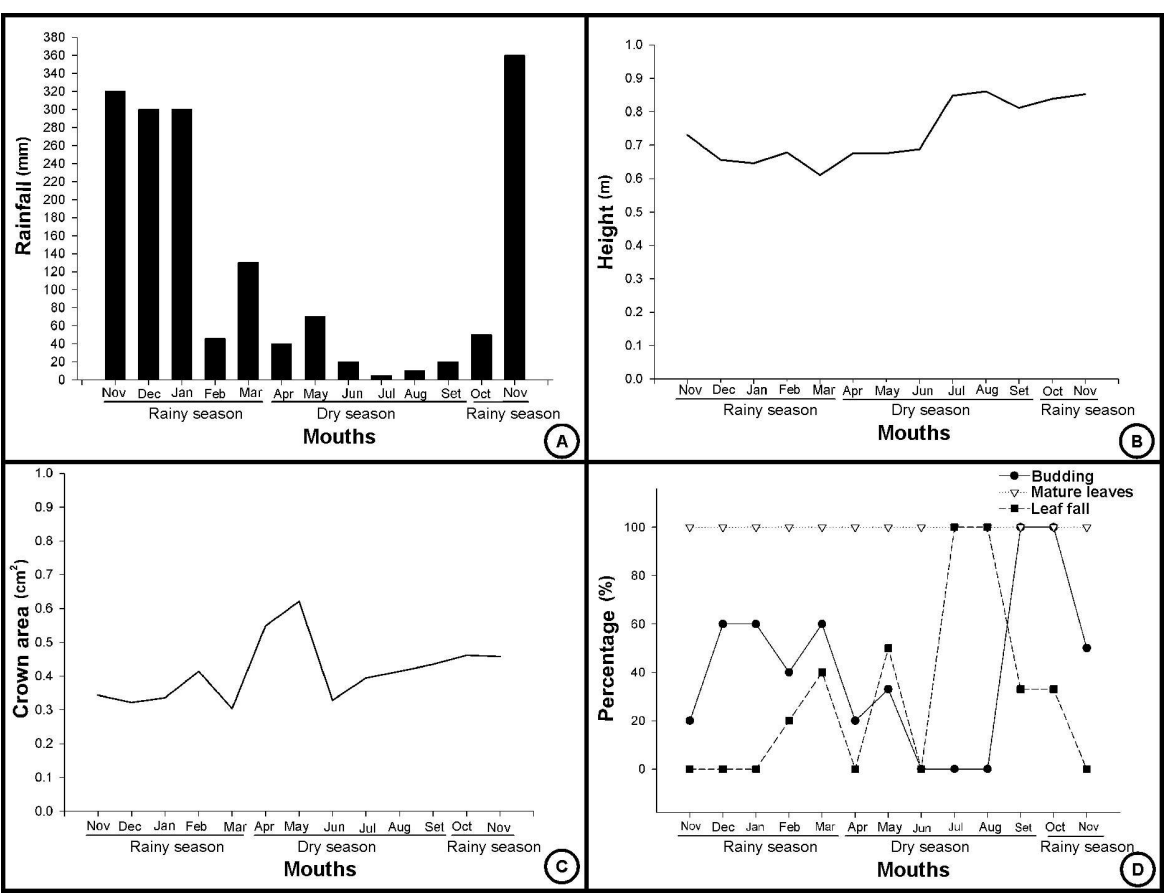

Figure 1 - Monthly accumulated rainfall (A) and average height (B), canopy area (C) and leaf phenology (D) of Campomanesia adamantium from the Rupestrian field among the rainy and dry seasons.

Figura 1 - Precipitação acumulada mensal (A) e médias da altura (B), da área da copa (C) e fenologia vegetativa (D) de Campomanesia adamantium no Campo Rupestre na estação chuvosa e seca.

Revista Árvore, Viçosa-MG, v.40, n.6, p.973-981, 2016 


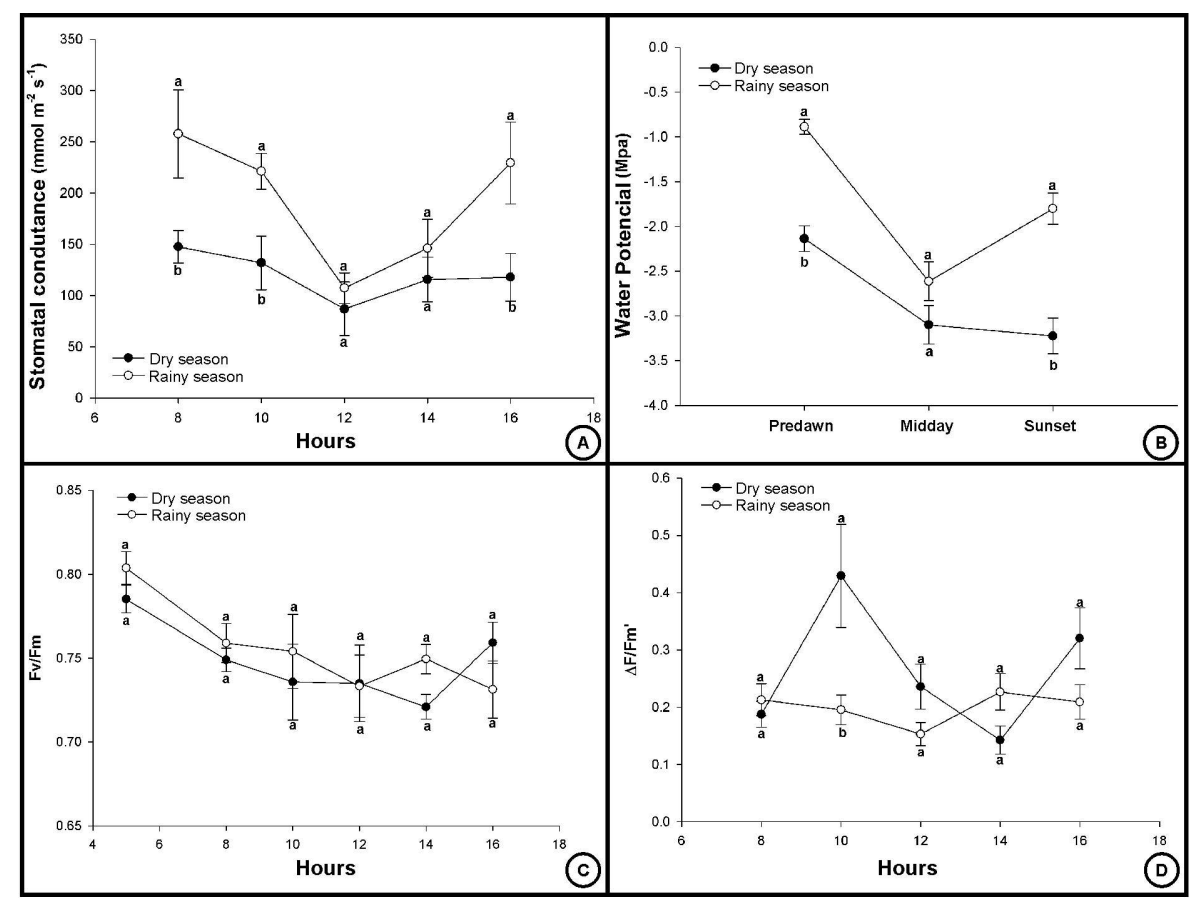

Figure 2 - Stomatal conductance average $\pm \mathrm{SE}(\mathrm{A})$, water potential $\pm \mathrm{SE}(\mathrm{B}), \mathrm{Fv} / \mathrm{Fm} \pm \mathrm{SE}(\mathrm{C})$ and $\Delta \mathrm{F} / \mathrm{Fm}{ }^{\prime} \pm \mathrm{SE}(\mathrm{D})$ of Campomanesia adamantium from the Rupestrian field among the rainy and dry seasons. $\mathrm{SE}=\mathrm{Standard}$ error. Note: Means followed by the same letter do not differ statistically between seasons.

Figura 2 - Médias da condutância estomática $\pm E P(A)$, do potencial hídrico $\pm E P(B)$, do $F v / F m \pm E P(C)$ e do $\Delta F /$ $F m^{\prime} \pm E P(D)$ de Campomanesia adamantium no Campo Rupestre na estação chuvosa e seca. EP= Erro padrão. Obs.: Médias seguidas pela mesma letra entre as estações não diferem estatisticamente.

\subsection{Stomatal conductance, chlorophyll $a$ fluorescence, leaf water status and pigments}

Stomatal conductance was highest at 08:00 h, 10:00 $\mathrm{h}$ and 16:00 $\mathrm{h}$, in the rainy season, varying from 146 to $257 \mathrm{mmol} . \mathrm{m}^{-2} \mathrm{~s}^{-1}$, in comparison to the dry season varying from 87 to $132 \mathrm{mmol} \cdot \mathrm{m}^{-2} \mathrm{~s}^{-1}$ (Figure 2A). Leaf water potential was lower in the predawn and dusk time periods in the dry season, being around -2,2 Mpa in the predawn in the dry season. In both seasons we observed a decrease in values in the middle of the day, with the most marked of such reductions being in the rainy season (Figure 2B). Values of FV/Fm did not exhibit differences between the seasons (Figure 2C). In both seasons the values were close to 0.8 throughout the day, being higher only at dawn for the rainy season (Figure 2C). Values of $\Delta \mathrm{F} /$ Fm' remained similar throughout the day, and only higher at 10:00 $\mathrm{h}$ in the dry season, with low average values (between 0.2 and 0.3 ) in both the dry and the rainy seasons (Figure 2C). The analysis of pigments showed a higher concentration of total chlorophyll, chlorophyll $a$, carotenoids and ratio of chlorophyll $a / b$ during the rainy season, and no difference in the ratio of total chlorophyll/carotenoids and chlorophyll $b$ between seasons (Table 1).

\section{DISCUSSION}

Precipitation is one of the factors that can affect vegetal development and plant phenology (BULHÃO; FIGUEIREDO, 2002; PIRANI et al., 2009). Although C. adamantium is evergreen and emits leaves for most of the year, the increase in leaf fall, especially during periods of greater water restriction, reinforces the idea that the species adopts strategies for dealing with the seasonal drought of the Rupestrian fields. This idea is reinforced by decreased values for stomatal conductance and leaf water potential in the dry season, which supports one of the hypotheses. However, the values of $\Delta \mathrm{F} / \mathrm{Fm}$ ' were relatively low and not very different

Revista Árvore, Viçosa-MG, v.40, n.6, p.973-981, 2016 
Table 1 - Photosynthetic pigments concentration of Campomanesia adamantium \pm SE from the Rupestrian field along the rainy and dry seasons. $\mathrm{SE}=$ Standard error. Note: Means followed by the same letter do not differ statistically between seasons.

Tabela 1 - Concentração de pigmentos fotossintéticos de Campomanesia adamantium \pm EP no Campo Rupestre na estação chuvosa e seca. EP=Erro padrão. Obs.: Médias seguidas pela mesma letra entre as estações não diferem estatisticamente.

\begin{tabular}{|c|c|c|c|c|c|c|c|c|c|c|c|}
\hline \multicolumn{12}{|c|}{ Seasons / Pigments $\left(\mathrm{mg} / \mathrm{cm}^{2}\right)$} \\
\hline \multicolumn{6}{|c|}{ Dry season } & \multicolumn{6}{|c|}{ Rainy season } \\
\hline Chl. $a$ & Chl. $b$ & Cars & Total & $\begin{array}{l}\text { Ch1. } a / \\
\text { Ch1. } b\end{array}$ & $\begin{array}{c}\text { Total } \\
\text { Ch1. / Cars }\end{array}$ & Chl. $a$ & Chl. $b$ & Cars & $\begin{array}{l}\text { Total } \\
\text { Chl. }\end{array}$ & $\begin{array}{l}\text { Ch1. } a / \\
\text { Ch1. } b\end{array}$ & $\begin{array}{c}\text { Total } \\
\text { Ch1. / Cars }\end{array}$ \\
\hline $\begin{array}{l}5,67 \pm \\
0,6 \mathbf{b} \\
\end{array}$ & $\begin{array}{c}7,37 \pm \\
0,9 \text { a }\end{array}$ & $\begin{array}{c}405,03 \pm \\
20 \mathbf{b}\end{array}$ & $\begin{array}{c}418,08 \pm \\
22 \mathbf{a}\end{array}$ & $\begin{array}{l}0,77 \pm \\
0,01 \text { b }\end{array}$ & $\begin{array}{c}1,03 \pm \\
0,003 \mathbf{a}\end{array}$ & $\begin{array}{l}11,18 \pm \\
0,39 \text { a }\end{array}$ & $\begin{array}{l}8,14 \pm \\
0,22 \text { a } \\
\end{array}$ & $\begin{array}{c}611,69 \pm \\
26,8 \text { a }\end{array}$ & $\begin{array}{c}631,02 \pm \\
27,2 \text { b }\end{array}$ & $\begin{array}{l}1,37 \pm \\
0,05 \mathbf{a}\end{array}$ & $\begin{array}{c}1,03 \pm \\
0 \mathbf{a}\end{array}$ \\
\hline
\end{tabular}

Chl. - Chlorophyll; Cars. - Carotenoids.

between the two seasons, and the values of Fv/Fm remained around 0.8 with no significant change between the rainy and dry seasons, showing that seasonal water restriction only slightly affected photosynthetic performance.

The phenological pattern observed in $C$. adamantium may have been responsible for its steady growth, beyond the influence of the characteristics of the soil of Rupestrian fields (i.e., shallow and not very fertile, which may hinder water retention; DIAS et al., 2003). According to Borchert et al. (2002), leaf loss during the dry season is a water conserving strategy for plants, being caused by the stimulation of leaf abscission by low relative humidity, as occurred with C. adamantium. The pronounced leaf abscission at the end of the dry season, and budding at the beginning of the rainy season, that occurred with C. adamantium may represent a reallocation of resources to the meristem, and a return to growth and tissue formation in the rainy season. Guilherme et al. (2011) suggested such reallocation because of the temporal proximity of budding and flowering in Cybistax antisyphilitica, strengthening the possibility of using these resources for the growth and formation of vegetal organs.

The marked seasonality of the Rupestrian field affected stomatal control between seasons in the individuals of $C$. adamantium evaluated, with stomatal closure during the period of greatest water restriction. Individuals of $C$. adamantium of the Cerrado of the upper Jequitinhonha region (Minas Gerais) also controlled stomatal opening, especially in the dry season in the middle of the day, with values around $87 \mathrm{mmol} . \mathrm{m}^{-2} \mathrm{~s}^{-}$ ${ }^{1}$ in the dry season and $378 \mathrm{mmol} . \mathrm{m}^{-2} \mathrm{~s}^{-1}$ in the rainy season (LEMOS-FILHO, 2000). In the present study, we also observed a decrease in the values of leaf water potential in C. adamantium, and especially in the middle of the day, in both the dry and rainy seasons, corroborating other studies that evaluated water status of species of the Cerrado (BUCCI et al., 2005; FRANCO et al., 2005; ROSSATTO et al., 2013).

The reduction of photosynthetic levels may be the result of stomatal closure in the dry season and in the rainy season, being more pronounced during periods of higher water deficit. This response was reported for individuals of Roupala montana of the Cerrado by Franco (1998). For C. adamantium, the marked seasonality in water availability did not bring large differences in photosynthetic efficiency since the Fv/Fm values were very stable and varied little throughout the day. Lüttge (1998) considered that Fv/ Fm values less than 0.8 , after 30 minutes of adaptation to dark, is indicative of photoinhibition of photosystem II in plants of Rupestrian field. Individual plants of C. adamantium showed photoinhibition in both seasons, but values higher than 0.8 were observed only at dawn during the rainy season, and may be associated with increased water availability during that period. In any case, the decrease in Fv/Fm values was relatively low throughout the day, even in the dry season, which reinforces the idea that this species can tolerate the seasonal water restriction in Rupestrian field. Lüttge et al. (2007), who evaluated photoinhibition in five species of Velloziaceae in Rupestrian fields of Serra do Cipó during the rainy season, also observed values greater than 0.8 at dawn, even with exposure of plants to solar radiation during the day. Higher values of $\Delta F /$ Fm' in the dry season during hot times of the day (10:00 h) reaffirms the ability of this species to adjust its physiology for better photosynthetic efficiency of PSII in conditions of high irradiance and seasonal water deficit.

Photosynthetic efficiency of plants, and consequently their ability to grow and adapt to various environments, is related to the concentration of pigments 
(ENGEL; POGGIANI, 1991). Although marked differences in photosynthetic efficiency between seasons was not observed for $C$. adamantium, an increase in photosynthetic pigments was seen during the rainy season, indicating a seasonal influence on this parameter. Increases in the concentrations of pigments during the rainy season were also reported by Carvalho et al. (2007) for plants of the Cerrado. These authors felt that the high concentration of chlorophylls in this season may be related to the presence of a new cohort of leaves. Thus, the high concentration of chlorophyll $a$ and carotenoids observed for C. adamantium in the rainy season may have contributed to $\mathrm{Fv} / \mathrm{Fm}$ values being greater than 0.8 in the early morning. This perception was based on the results of Gomes et al. (2008), who found higher photoinhibition in plants with low carotenoid and chlorophyll content when grown unshaded.

\section{CONCLUSION}

Campomanesia adamantium is an evergreen species and features mature leaves and buds throughout the year, with an increase in leaf fall in the periods with the greatest water deficit. Pronounced leaf abscission at the end of the dry season and budding at the beginning of the rainy season suggest reallocation of resources. These reductions were accompanied by more negative values of water potential, reaching $-3,0 \mathrm{Mpa}$ in the middle of the day, which triggered greater restriction to stomatal opening. These results in the dry season show strategies that minimize the loss of water, which is scarce in Rupestrian fields during this season. However, the seasonal water deficit had little effect on the photosynthetic performance of C. adamantium, which is critical to building new leaves and renewing the canopy in the dry season. Finally, the low variation in Fv/Fm values throughout the day, even under water restriction, associated with the increase in $\Delta \mathrm{F} / \mathrm{Fm}$ ' values during the time of the day with high light exposure in the dry season, reiterates the ability of $C$. adamantium to respond well to seasonal water deficit typical of Rupestrian fields.

\section{REFERENCES}

BAKER, N.R. Light-use efficiency and photoinhibition of photosynthesis in plants under environmental stress. In: SMITH, J.A.C.; GRIFFITHS, H. (Ed.). Water deficit plant responses from cell to community.
Oxford: Bios Scientific Publication, 1993. p.221235.

BELO, R.M.; NEGREIROS, D.; FERNANDES, G.W.; SILVEIRA, F.A.O.; RANIERI, B.D.; MORELLATO, P.C. Fenologia reprodutiva e vegetativa de arbustos endêmicos de campo rupestre na Serra do Cipó, Sudeste do Brasil. Rodriguésia, v.64, n.4, p.817-828, 2013.

BORCHERT, R.; RIVERA, G.; HAGNAUER, W. Modification of vegetative phenology in a tropical semideciduous forest by abnormal drought and rain. Biotropica, v.34, p.27-39, 2002.

BUCCI, S.J.; GOLDSTEIN, G.; MEINZER, F.C.; FRANCO, A.C.; CAMPANELLO, P.; SCHOLZ, F.G. Mechanisms contributing to seasonal homeostasis of minimum leaf water potential and predawn disequilibrium between soil and plant water potential in Neotropical savanna tree. Trees, v.19, p.296-304, 2005.

BULHÃO, F.C.; FIGUEIREDO, P.S. Fenologia de leguminosas arbóreas em uma área de cerrado marginal no nordeste do Maranhão. Revista Brasileira de Botânica, v.25, n.3, p.361-369, 2002.

CARVALHO, A.P.F.; BUSTAMANTE, M.M.C.; KOZOVITS, A.R.; ASNER, G.P. Variações sazonais nas concentrações de pigmentos e nutrientes em folhas de espécies de cerrado com diferentes estratégias fenológicas. Revista Brasileira de Botânica, v.30, p.17-25, 2007.

CASTRO, S.A.B.; SÁ, C.E.M.; MOURÃO, F.A.; DUARTE, H.M.; FERNANDES, G.W; LEMOS-FILHO, J.P. Ecophysiological performance of a threatened shrub under restored and natural conditions in harsh tropical mountain environments. Acta Botanica Brasilica, v.30, p.17-26, 2016.

DIAS, H.C.T.; SCHAEFER, C.E.G.R.; FERNANDES FILHO, E.I.; OLIVEIRA, A.P.; MICHEL, R.F.M.;LEMOS JR, J.B. Caracterização de solos altimontanos em dois transectos no Parque Estadual do Ibitipoca (MG). Revista Brasileira de Ciência do Solo, v.27, n.3, p.469-481, 2003.

EITEN, G. The Cerrado vegetation of Brazil. Botanical Review, v. 38, n.2, p. 201-341, 1972.

Revista Árvore, Viçosa-MG, v.40, n.6, p.973-981, 2016

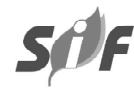


EITEN, G. Vegetação natural do Distrito Federal. Brasília: UnB, 2001.

ENGEL, V.L.; POGGIANI, F. Estudo da concentração de clorofila nas folhas e seu espectro de absorção de luz em função do sombreamento em mudas de quatro espécies florestais nativas. Revista Brasileira de Fisiologia Vegetal, v.3, p.39-45, 1991.

FRANCO, A.C. Seasonal patterns of gas exchange, water relations and growth of Roupala montana, an evergreen species. Plant Ecology, v.136, p.69-76, 1998.

FRANCO, A.C. Ecophysiology of woody plants. In: OLIVEIRA, P.S.; MARQUIS, R.J. (Ed.). The Cerrados of Brazil. New York: Columbia University Press, 2002. p.178-197.

FRANCO, A.C.; BUSTAMANTE, M.; CALDAS, L.S.; GOLDSTEIN, G.; MEINZER, F.C.; KOZOVITS, A.R.; RUNDEL, P.; CORADIN, V.R.T. Leaf functional traits of Neotropical savanna trees in relation to seasonal water deficit. Trees, v.19, p.326-335, 2005.

GENTY, B.; BRIANTAIS, J.M.; BAKER, N.R. The relationship between the quantum yield of photosynthetic electron transport and quenching of chlorophyll fluorescence. Biochimica Biophysica Acta, v.990, p.87-92, 1989.

GIULIETTI, A.M.; MENEZES, N.L.; PIRANI, J.R.; MEGURO, M.; WANDERLEY, M.G.L. Flora da Serra do Cipó, Minas Gerais: caracterização e lista das espécies. Boletim de Botânica da Universidade Federal de São Paulo, v.9, p.1-151, 1987.

GIULIETTI, A.M.; PIRANI, J.R.; HARLEY, R.M. Espinhaço range region, eastern Brazil. In: DAVIS, S.D.; HEYWOOD, V.H.; HERRERA-MACBRYDE, O.; VILLA- LOBOS, J.; HAMILTON, A.C. (Eds.). Centres of plant diversity: a guide and strategy for their conservation. Cambridge: WWF/ IUCN, 1997. p.397-404.

GIULIETTI, A.M.; HARLEY, R.M.; QUEIROZ, L.P.; WANDERLEY, M.G.L.; PIRANI, J.R. Caracterização e endemismos nos campos rupestres da Cadeia do Espinhaço. In: CAVALCANTI, T.B.; WALTER, B.M.T. (Eds.). Tópicos atuais em
Botânica. Brasília: Sociedade Brasileira de Botânica/Embrapa, 2000.

GOMES, I.A.C.; CASTRO, E.M.; SOARES, A.M.; ALVES, J.D.; ALVARENGA, M.I.N.; ALVES, E.; BARBOSA, J.P.R.A.D.; FRIES, D.D. Alterações morfofisiológicas em folhas de Coffea arabica L. cv. Oeiras sob influência do sombreamento por Acacia mangium Willd. Ciência Rural, v.38, p.109-115, 2008 .

GUILHERME, F.A.G.; SALGADO, A.A.; COSTA, E.A.; ZORTÉA, M. Fenologia de Cybistax antisyphilitica (MART.) MART. (Bignoniaceae) na região urbana de Jataí, Goiás. Bioscience Journal, v.27, p.138-147, 2011.

INSTITUTO NACIONAL DE METEOROLOGIA INMET. [acessado em: 05 Ago. 2015] Disponível em: <http://www.inmet.gov.br/>.

KAWASAKI, M.L. A new species of Campomanesia (Myrtaceae) from southeastern Brazil. Brittonia, v.52, p.188-190, 2000.

KOLBEK, J.; ALVES, R.J.V. Impacts of cattle, fi re and wind in Rocky Savannas, Southeastern Brazil Acta Universitatis Carolinae Environmentalica, v.22, p.111-130, 2008.

KRAUSE, G.H.; WEIS, E. Chlorophyll fluorescence and photosynthesis: the basics. Annual Review of Plant Physiology and Plant Molecular Biology, v.42, p.313-349, 1991.

LANDRUM, L.R. The development of the fruits and seeds of Campomanesia (Myrtaceae). Brittonia, v.34, p.220-224, 1982.

LEMOS-FILHO, J.P. Fotoinibição em espécies do cerrado. Revista Brasileira de Botânica, v. 23, p. $45-50,2000$.

LICHTENTHALER, H.K.; WELLBURN, A.R. Determinations of total carotenoids and chlorophylls $a$ and $b$ of leaf extracts in different solvents. Biochemical Society Transaction, v.11, p.591-592, 1983.

LORENZI, H.; BACHER, L.; LACERDA, M.; SARTORI, S. Frutas brasileiras exóticas cultivadas: de consumo in natura. São Paulo: Instituto Plantarum de Estudos da Flora, 2006. 
LÜTTGE, U.; DUARTE, H.M.; SCARANO, F.R.; MATTOS, E.A.; CAVALIN, P.O.; FRANCO, A.C.; FERNANDES, G.W. Physiological ecology of photosynthesis of five sympatric species of Velloziaceae in the rupestrian fields of Serra do Cipó, Minas Gerais, Brazil. Flora, v.202, p.637646, 2007.

LÜTTGE, U.; HARIDASAN, M.; FERNANDES, G.W.; MATTOS, E.A.;TRIMBORN, P.; FRANCO, A.C.; CALDAS, L.S.; ZIEGLER, H. Photosynthesis of mistletoes in relation to their hosts at various sites in tropical Brazil. Trees, v.12, p.167-174, 1998.

MEINZER, F.C.; GOLDSTEIN, G.; FRANCO, A.C.; BUSTAMANTE, M.; IGLER, E.; JACKSON, P.; CALDAS L.S.; RUNDEL, P.W. Atmospheric and hydraulic limitations on transpiration in Brazilian cerrado woody species. Functional Ecology, v.13, p.273-282, 1999.

MENDONÇA, M.P.; LINS, D.A. Lista vermelha de espécies ameaçadas de extinção da flora de Minas Gerais. Belo Horizonte: Fundação Biodiversistas, 2000.

NAVES-BARBIERO, C.C.; FRANCO, A.C.; BUCCI, S.J.; GOLDSTEIN, G. Fluxo de seiva e condutância estomática de duas espécies lenhosas sempreverdes no campo sujo e cerradão. Revista Brasileira de Fisiologia Vegetal, v.12, p.119-134, 2000.

NEVES, S.P.S.; CONCEIÇÃO, A.A. Campo rupestre recém-queimado na Chapada Diamantina, Bahia, Brasil: plantas de rebrota e sementes, com espécies endêmicas na rocha. Acta Botanica Brasilica, v.24, n.3, p.697-707, 2010.

OLIVEIRA, P.E. Fenologia e biologia reprodutiva das espécies de cerrado. In: SANO, S.M.; ALMEIDA, S.P. (Eds.). Cerrado: ambiente e flora. Planaltina: Embrapa-CPAC, 1998. p.169-192.

PIRANI, F.R.; SANCHEZ, M.; PEDRONI, F. Fenologia de uma comunidade arbórea em cerrado sentido restrito, Barra do Garças, MT. Acta Botânica Brasílica, v.23, n.4, p.1096-1109, 2009.

PIVA, M.G. O caminho das plantas medicinais: Estudo Etnobotânico. Rio de Janeiro: Mondrian, 2002.
RASCHER, U.; LIEBIG, M.; LÜTTGE, U.

Evaluation of instant light-response curves of chlorophyll fluorescence parameters obtained with a portable chlorophyll fluorometer on site in the field. Plant, Cell and Environmental, v.23, p.1397-1405, 2000.

RAPINI, A.; RIBEIRO, P.L.; LAMBERT, S.; PIRANI, J.R. A flora dos campos rupestres da Cadeia do Espinhaço. Megadiversidade, v.4, n.1, p.16-24, 2008.

ROSSATTO, D.R.; HOFFMANN, W.A.; SILVA, L.C.R.; HARIDASAN, M.; STEMBERG, L.S.L.; FRANCO, A.C. Seasonal variation in leaf traits between congeneric savanna and forest trees in Central Brazil: implications for forest expansion into savana. Trees, v.27, p.1139-1150, 2013.

SARMIENTO, G.; GOLDSTEIN, G.; MEINZER, F. Adaptative strategies of woody species in neotropical Savannah. Biological Review, v.60, p.315-355, 1985.

SILVEIRA, F.A.O.; NEGREIROS, D.; BARBOSA, N.P.U.; BUISSON, E.; CARMO, F.F.; CARSTENSEN, D.W.; CONCEIÇÃO, A.A.; CORNELISSEN, T.G.; ECHTERNACHT, L.; FERNANDES, G.W.; GARCIA, Q.S.; GUERRA, T.J.; JACOBI, C.M.; LEMOSFILHO, J.P.; STRADIC, S.L.; MORELLATO, L.P.C.; NEVES, F.S.; OLIVEIRA, R.S.; SCHAEFER, C.E.; VIANA, P.L.; LAMBERS, H. Ecology and evolution of plant diversity in the endangered campo rupestre: a neglected conservation priority. Plant and Soil, v. 403, p.129-152, 2016.

SOUZA, G.S.; CASTRO, E.M.; SOARES, Â.M.; SANTOS, A.R.; ALVES, E. Photosynthetic pigments content, photosynthesis rate and chloroplast structure in young plants of Mikania laevigata Schultz Bip. ex Baker grown under colored nets. Semina: Ciências Agrárias, v.32, p.18431854, 2011.

VALLILO, M.I.; LAMARDO, L.C.A.; GARBELOTTI, M.L.; OLIVEIRA, E.; MORENO, P.R.H. Composição química dos frutos de Campomanesia adamantium (Cambessédes) O. Berg. Ciência e Tecnologia de Alimentos, v.26, p.805-810, 2006.

VASCONCELOS, M.F. O que são campos rupestres e campos de altitude nos topos de montanha do Leste do Brasil? Revista Brasileira de Botânica, v.34, n.2, p.241-246, 2011.

Revista Árvore, Viçosa-MG, v.40, n.6, p.973-981, 2016

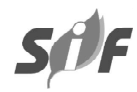

